\title{
Changes in active compounds and biological activities during fermentation of soy-powder milk by the mixtures of probiotics lactic acid bacteria
}

\author{
Chung Eun Hwang ${ }^{1,2}$, Du Yong Cho ${ }^{1}$, Jin Hwan Lee ${ }^{3}$, Dong Hee Lee ${ }^{4}$, Kye Man Cho ${ }^{1 *}$ \\ ${ }^{1}$ Department of Food Science, Gyeongnam National University of Science and Technology, Jinju 52725, Korea \\ ${ }^{2}$ Department of Research and Development, Jinju Bio Industry Foundation, Jinju 52839, Korea \\ ${ }^{3}$ Department of Life Resources Industry, Dong-A University, Busan 49315, Korea \\ ${ }_{4}^{4}$ Industry Academy Cooperation Foundation, Andong National University, Andong 36729, Korea
}

\section{복합 생균제제 유산균에 의한 콩-분말 두유 발효에 따른 유효성분 및 생리활성 변화}

\author{
황정은 ${ }^{1,2} \cdot$ 조두용 $^{1} \cdot$ 이진환 $^{3} \cdot$ 이동희 $^{4} \cdot$ 조계만 $^{1 *}$ \\ 1경남과학기술대학교 식품과학부, ${ }^{2}$ (재)진주바이오산업진흥원 연구개발실, \\ ${ }^{3}$ 동아대학교 생명자원산업학과, ${ }^{4}$ 안동대학교 산학협력단
}

\begin{abstract}
This study evaluated changes in $\gamma$-aminobutyric acid (GABA), isoflavones, and antioxidant activities during fermentation of soy-powder milk (SPM) by Lactobacillus brevis WCP02 and Lactobacillus plantarum P1201 starters. The levels of glutamic acid (GA) were significantly increased during first $24 \mathrm{~h}$ of SPM $(100.38 \rightarrow 290.13 \mathrm{mg} / 100 \mathrm{~g})$ then decreased after $72 \mathrm{~h}$ of SPM to $177.91 \mathrm{mg} / 100 \mathrm{~g}$. The GABA contents obviously increased from $32.05 \mathrm{mg} / 100$ $\mathrm{g}$ to $76.22 \mathrm{mg} / 100 \mathrm{~g}$ between 0 and $72 \mathrm{~h}$ of SPM. Levels of isoflavone-glycosides, including daidzin, glycitin, and genistin, significantly decreased $(746.23 \rightarrow 24.04 \mu \mathrm{g} / \mathrm{g}, 183.52 \rightarrow 76.00 \mu \mathrm{g} / \mathrm{g}$, and $980.72 \rightarrow 10.08 \mu \mathrm{g} / \mathrm{g}$, respectively), as levels of isoflavone aglycones, such as daidzein, glycitein, and genistein, significantly increased $(52.03 \rightarrow 577.01$ $\mu \mathrm{g} / \mathrm{g}, 12.95 \rightarrow 66.48 \mu \mathrm{g} / \mathrm{g}$, and $38.62 \rightarrow 462.42 \mu \mathrm{g} / \mathrm{g}$, respectively) during fermentation of SPM. The antioxidant activity and inhibitory effect on digestive enzyme $(1 \mathrm{mg} / \mathrm{mL})$ also considerably increased during fermentation of SPM: DPPH $(30.23 \rightarrow \mathbf{8 8 . 5 0} \%)$, ABTS $(59.71 \rightarrow 74.54 \%)$, and hydroxyl $(65.51 \rightarrow 76.10 \%)$ radical scavenging activities and pancreatic lipase $(8.00 \rightarrow 34.53 \%)$ and $\alpha$-glucosidase inhibition $(12.38 \rightarrow 45.38 \%)$ activities.
\end{abstract}

Key words : $\gamma$-aminobutyric acid, soybean, isoflavone, lactic acid fermentation, digestive enzyme inhibitory

서 론

콩(Glycine $\max$ L.) 이소플라본(isoflavone)은 여성 호르몬 과 구조가 매우 유사하여 식물성 에스트로겐(phytoestrogen) 으로 분류된다(Brouns, 2002). 식물성 에스트로겐인 이소플
라본은 크게 배당체와 비배당체로 나눌 수 있으며, 비배당체 형태는 daidzein, glycitein 및 genistein이 알려져 있다. 또한, 배당체는 daidzin, glycitin, genistin이 대표적이며, 이외에 malonyl-daidzin, malonyl-glycitin, malonyl-genistin, acetyldaidzin, acetyl-glycitin, acetyl-genistin이 존재하지만, 이 화

\footnotetext{
*Corresponding author. E-mail : kmcho@gntech.ac.kr, Phone : +82-55-751-3272, Fax : +82-55-751-3279

Received 26 August 2020; Revised 23 September 2020; Accepted 24 September 2020.

Copyright (c) The Korean Society of Food Preservation.

This is an Open Access article distributed under the terms of the Creative Commons Attribution Non-Commercial License (http://creativecommons.org/licenses/by-nc/4.0) which permits unrestricted non-commercial use, distribution, and reproduction in any medium, provided the original work is properly cited.
} 
합물들은 콩에 미량 존재하는 것으로 알려져 있다(Hwang 등, 2018c). 콩 이소플라본은 일반적으로 배당체 형태로 대부 분 존재하지만, 이들 함량과 존재 형태는 대두 품종, 가공조 건(가열온도, 발아, 발효, 미생물)에 따라 다양하게 변화된다 (Matsuda 등, 1994). 이 밖에도 갱년기 완화와 골다공증 등에 도 효능이 있는 것으로 보고되었다(Coward 등, 1993; Lee 등, 2005).

콩은 단백질의 대명사로써 단백질에 의해 각종 아미노산 역 시 다량 존재하며, 숙취 해소에 좋다고 알려진 아스파라긴산 (asparaginic acid)을 비롯한 산성 아미노산과 여러 필수 아미노 산(valine, isoleucine 등)들도 함유되어 있다. $\gamma$-Aminobutyric $\operatorname{acid}(\mathrm{GABA})$ 의 대사경로는 신경전달물질인 만큼 복잡한 TCA cycle을 통하여 여러 종류의 아미노산 합성을 거쳐 생 성되는 구조이며, 크게 glutamate decarboxylase(GAD) 활성 과 탈탄산 반응에 의해 글루탐산으로부터 $\mathrm{GABA}$ 로 전환된 다(Hwang 등, 2018b). GABA는 오래전부터 현미(An 등, 2010), 보리(Cha 등, 2012) 등에 다량 함유되어 있는 것으로 보고되었으나, 그 함량이 매우 적은 결과로 $\mathrm{GABA}$ 의 약리작 용을 나타내기에는 사실상 기대하기 어려운 실정이다. 따라 서 이 문제를 해결하는 방안으로 최근에는 미생물 제제를 이 용하여 생물전환기술을 적용해 $\mathrm{GABA}$ 함량을 증가시키는 연구가 보고되었으며(Hwang 등, 2018c), An 등(2010)은 현 미 발아를 통해 GABA 함량 증대에 성공하였고 $\mathrm{Pyo}(2008)$ 는 홍국균을 이용하여 콩으로부터 $\mathrm{GABA}$ 합성에 성공한 연구 결과를 보고하였다.

콩을 유산발효시킨 형태의 콩 혹은 두유 요구르트는 우유 를 발효시킨 일반적인 요구르트와는 다르게 부족한 영양성분 을 섭취할 수 있으며, 특히 유당을 함유하고 있지 않아 유당 불내증 환자들에게는 아주 훌륭한 우유 대체 식품이기도 하 다(Hwang 등, 2018c). 현재까지 두유 연구 결과에 따르면, 두 유는 수용성 단백질과 다량의 불포화 지방산을 함유하고 있 어 체내 콜레스테롤 침착을 저해시킬 수 있고, 성인병 예방에 탁월하다고 보고되었다(Hwang 등, 2018d). 그러나 이렇게 풍부한 영양학적인 가치를 지닌 콩도 몇 가지 단점이 있으며, 특히 lipoxygenase는 특유의 비린내를 생성하는 효소로 기호 성을 저하시키고, flatulence, trypsin 저해제, phytic acid 등의 장내 가스 생성 유발물질들이 함유되어 있어 제거할 필요가 있다(Yang 등, 2013). 이러한 콩 비린내와 가스 생성물질을 제거하려는 방법의 하나로 발효공법을 이용한 연구가 많이 진행되었다(Lee 등, 2019). 또한, 이미 오래전부터 여러 품종 의 콩을 이용한 요구르트 연구는 많이 진행되었고 특히, 최근에 는 유색 소립콩(Hwang 등, 2018c), 갈색콩(Hwang 등, 2016a), 품종별 장류콩(Hwang 등, 2016b) 이용 두유 요구르트의 phytochemical 함량 변화에 관한 연구가 보고되었다.
그러나, 과거부터 현재까지 다양한 품종(색, 크기 등)의 콩 에 대한 연구는 많이 이루어져 왔으나 여러 품종에 비해 낱알 이 크고 기계 수확률이 매우 뛰어나 장류와 두부 가공 적성에 탁월한 품종(Ko 등, 2016)인 우람콩에 관한 연구결과는 미비 한 것으로 조사되었다. 따라서 본 연구에서는 우람콩을 주 원 료로 하여 콩-분말 두유를 제조하고, 비배당체 isoflavone 생 성 우수 균주인 Lactobacillus plantarum P1201(Hwang 등, 2016b)과 GABA 생성 우수 균주인 Lactobacillus brevis WCP02(Hwang 등, 2018c)를 복합적으로 사용하여 미생물 발 효공정을 적용시킨 콩-분말 두유에서 기능성 물질인 isoflavone 과 $\mathrm{GABA}$ 를 동시에 다량 생성할 수 있는 최적 발효조건에 대한 결과를 보고하는 바이다.

\section{재료 및 방법}

\section{실험재료, 미생물 및 시약}

본 연구에서 사용한 우람콩(Glycine max Merr) 품종은 농 촌진흥청에서 재배와 수확된 것을 제공받아 사용하였다. 본 연구에서 사용한 생균제제 유산균은 김치 등의 발효식품으로 부터 분리한 후 잠재적인 생균제제능이 확인된 Lactobacillus brevis WCP02(Hwang 등, 2018a)와 Lactobacillus plantarum P1201(Lee 등, 2018b) 균주를 사용하였다. 유산균 배양은 MRS broth/agar(MRSB/MRSA, Difco, Becton Dicknson Co., Sparks, MD, USA)를 사용하여 상황에 따라 액체 또는 고체 배양하였다. 6 종류의 isoflavone 유도체 중 비배당체 형태의 daidzein, glycitein과 genistein 및 배당체 형태의 daidzin, glycitin과 genistin는 Sigma-Aldrich(St. Louis, MO, USA)에 서 구입하였다. 항산화 활성과 소화효소 저해활성 측정에 사 용한 시약 중 2,4,6-azino-bis(3-ethylbenzthiazoline-6-sulphnoic acid)(ABTS), 2,2-diphenyl-1-picrydrazyl(DPPH), trifluoroacetic acid(TCA), thiobarbituric acid(TBA), $p$-nitrophenyl- $\alpha$-D-glucopyranoside( $p$-NPG), $p$-nitrophenyl-butyrate( $p$-NPB), $\alpha$-glucosidase 및 pancreatic lipase 역시 Sigma-Aldrich에서 구입 하여 사용하였다. Methanol, acetonitrile, water 및 acetic acid 등의 시약 및 유기용매는 J.T. Baker사(Philipsbug, NJ, USA) 에서 구입하여 사용하였으며, 그 외 기타 시약은 필요에 따라 서 분석용 1 급 또는 특급 시약을 구입하여 사용하였다.

\section{분석기기}

유리아미노산 분석은 아미노산 자동분석기(L-8900, Hitachi High-Technologies Corp., Tokyo, Japan)를 사용하여 수행하 였으며, isoflavone 분석은 high performance liquid chromatography(HPLC, Agilent 1200 system, Agilent Technologies Inc., Waldbronn, Germany)를 사용하였다. 이 외 라디칼 소 
거활성 및 소화효소 저해활성 측정은 분광광도계(UV-1800 240V, Shimadzu Corp., Kyoto, Japan)를 사용하였다.

\section{복합 생균제제 유산균 이용 발효 콩-분말 두유 제조}

두유 제조 전, Lactobacillus plantarum P1201와 Lactobacillus brevis $\mathrm{WCP} 02$ 균주를 각각 $\mathrm{MRS}$ 액체배지에 일정량 취하여 $37^{\circ} \mathrm{C}$ 에서 3 일간 세포수가 $10^{8}-10^{9}$ 이상 되도록 배양하여 종 균을 준비하였다. 우람콩 $(1 \mathrm{~kg})$ 을 12 시간 가량 물에 불리고 물기 제거 후, $100^{\circ} \mathrm{C}$ 에서 30 분간 증자한 후 $45^{\circ} \mathrm{C}$ 에서 2 일간 건조하고 분쇄하여 콩 분말을 준비하였다. 준비된 콩 분말 20 $\mathrm{g}$ 에 증류수 $(180 \mathrm{~mL})$, 설탕 $(5.0 \mathrm{~g})$ 을 첨가 및 혼합한 다음 12 $1{ }^{\circ} \mathrm{C}$ 에서 15 분간 살균하여 콩 분말 두유를 제조하였다. 여기 에 준비된 종균 $5 \mathrm{~mL}$ 를 접종시키고, $37^{\circ} \mathrm{C}$ 에서 72 시간 동안 발효시켜 최종적으로 발효 콩 분말 두유를 제조하였다.

\section{$\mathrm{pH}$, 산도 및 생균수 변화 측정}

발효 시간별 콩 분말 두유 $1 \mathrm{~mL}$ 를 취하여 $\mathrm{pH}$ 미터기(MP 220 , London, UK)로 측정하였고, 산도는 증류수 $49 \mathrm{~mL}$ 와 각각의 시료 $(1 \mathrm{~mL})$ 를 첨가하고 $0.1 \mathrm{~N} \mathrm{NaOH}$ 용액으로 중화 적정하였으며, 최종적으로는 lactic acid로 환산하여 백분율 로 나타내었다.

생균수 측정은 유산균 접종이 완료된 각각의 발효두유 1 $\mathrm{mL}$ 를 $10^{2}-10^{10}$ 수준으로 단계별로 희석을 하고, 그 희석액 $0.1 \mathrm{~mL}$ 를 미리 제조한 MRSA 배지에 분주하여 도말봉으로 골고루 펼친 후 $37^{\circ} \mathrm{C}$ 에서 48 시간 배양 후 생성된 집락수를 측정하여 $\mathrm{CFU} / \mathrm{mL}$ 로 나타내었다.

\section{유리아미노산 분석}

유리아미노산 분석은 각 시료를 동결건조한 후 분쇄하여 분말을 준비하였다. 분말 $1 \mathrm{~g}$ 에 HPLC water $5 \mathrm{~mL}$ 를 가한 후 $60^{\circ} \mathrm{C}$ 에서 가수분해 과정을 1 시간 진행하였다. 이 가수분 해물에 $10 \% 5$-sulfosalicylic acid를 $2 \mathrm{~mL}$ 가하고, $4^{\circ} \mathrm{C}$ 에서 2 시간 방치시켜 단백질을 침전시키며, $5,000 \mathrm{rpm}$ 의 속도로 3 분간 원심분리하여 수용액층을 $60^{\circ} \mathrm{C}$ 에서 감압 농축시켜 0.2 $\mathrm{N}$ lithium citrate buffer(pH 2.2) $2 \mathrm{~mL}$ 로 용해하고 $0.45 \mu \mathrm{m}$ membrane filter(pore size $0.45 \mu \mathrm{m}$, Advantec MFS, Japan) 로 여과한 후, 아미노산 자동분석기로 정량하여 $\mathrm{mg} / 100 \mathrm{~g}$ 으 로 나타내었다(Hwang 등, 2018a).

\section{추출물 제조}

추출물 제조는 Hwang 등(2018a)의 방법에 따라 각각의 분 말 $2 \mathrm{~g}$ 에 $80 \%$ 발효 주정 $40 \mathrm{~mL}$ 를 가하고, $25^{\circ} \mathrm{C}$ 에서 $12-16$ 시간 정도 교반시키고 원심분리하여 상등액을 $0.45 \mu \mathrm{m}$ membrane filter로 여과한 후 일부는 isoflavone 분석에 사용하였다. 나
머지는 최종 농도를 $1 \mathrm{mg} / \mathrm{mL}$ 로 제조하고, 이는 항산화 활성 및 소화효소 저해활성 측정에 사용하였다.

\section{Isoflavone 분석}

Isoflavone 분석은 Lee 등(2019)의 방법에 준하여 HPLC 로 정량 분석하였다. Column은 Lichrophore $100 \mathrm{RP} \mathrm{C}_{18}$ (Merck KGaA, $125 \mathrm{~mm} \times 4 \mathrm{~mm}, 5 \mu \mathrm{m}$, Darmstadt, Germany) 을 사용하였으며, 이동상 용매 $\mathrm{A}(0.2 \%$ glacial acetic acid in water $)$ 와 $\mathrm{B}(0.2 \%$ acetonitrile in glacial acetic acid $)$ 로 구성하 여 분석을 수행하였다. 각 용매 구배 조건은 B 용매를 기준으 로 $0 \%(0$ 분 $), 10 \%$ (15분), $20 \%$ ( 25 분), $25 \%$ (35분), $35 \%(45-50$ 분)로 유지하였다. 각 샘플의 주입량은 $20 \mu \mathrm{L}$ 로 설정하였고, 이동상 속도는 $30^{\circ} \mathrm{C}$ 에서 분당 $1 \mathrm{~mL}$ 의 유속을 유지하여 254 $\mathrm{nm}$ 의 diode array detector(DAD)에서 배당체(daidzin, glycitin, genistin)와 비배당체(daidzein, glycitein, genistin) 6종류를 검출하였다.

\section{라디칼 소거활성 측정}

$\mathrm{DPPH}$ 및 ABTS 라디칼 소거활성은 Cho 등(2018)의 방법 에 기술된 것을 바탕으로 수행하였다. DPPH 라디칼 소거활 성은 각각의 추출물 $(10 \mathrm{mg} / \mathrm{mL}) 0.2 \mathrm{~mL}$ 를 시험관에 취하고, $\mathrm{DPPH}\left(1.5 \times 10^{-4} \mathrm{M}\right)$ 용액 $0.8 \mathrm{~mL}$ 를 가하여 암실에서 15 분간 반응시켜 $527 \mathrm{~nm}$ 에서 흡광도를 측정하였다.

$\mathrm{ABTS}$ 라디칼 소거능은 메탄올 $(50 \mathrm{~mL})$ 에 ABTS 용액(7.4 $\mathrm{mM}$ )과 $2.6 \mathrm{mM}$ 의 potassium persulphate를 1:1로 혼합하여 12-16시간 동안 암실에서 ABTS 양이온을 형성시켰다. 이후 $732 \mathrm{~nm}$ 에서 흡광도의 값이 $0.8 \pm 0.02$ 가 되도록 메탄올로 조 정하고, 조정된 $\mathrm{ABTS}$ 용액 $0.9 \mathrm{~mL}$ 에 각각의 추출물 $0.1 \mathrm{~mL}$ 를 가하여 정확히 3 분후에 $732 \mathrm{~nm}$ 에서 측정하였다(Cho 등, 2018).

Hydroxyl 라디칼 소거능은 시험관에 $10 \mathrm{mM}$ FeSO4EDTA(10 mM, $0.15 \mathrm{~mL})$, 2-deoxylribose $(10 \mathrm{mM}, 0.15 \mathrm{~mL})$, $\mathrm{H}_{2} \mathrm{O}_{2}(10 \mathrm{mM}, 0.15 \mathrm{~mL})$ 각각의 추출물 $1.2 \mathrm{~mL}$ 를 차례로 가 한 후 $37^{\circ} \mathrm{C}$ 에서 4 시간 반응을 수행하였다. 이 반응액에 $1 \%$ $\mathrm{TBA}$ 와 $2.8 \% \mathrm{TCA}$ 를 $1 \mathrm{~mL}$ 씩 가한 후 $100^{\circ} \mathrm{C}$ 에서 20 분간 발 색시키고 냉각 후 $525 \mathrm{~nm}$ 에서 흡광도 변화를 측정하였다 (Lee 등, 2018a).

\section{소화효소 저해활성 측정}

소화효소 저해활성 측정은 탄수화물( $\alpha$-glucosidase)과 지방 (pancreatic lipase) 분해효소 두 가지를 Lee 등(2019)과 Hwang 등(2018d)의 방법에 따라 실시하였다. $\alpha$-Glucosidase 저해활 성은 $200 \mathrm{mM}$ sodium phosphate buffer(pH 7.0)에 $p$-NPG를 용해시켜 최종 $5 \mathrm{mM}$ 농도로 기질을 제조하였고 각각의 추출 
물과 기질용액을 $1.0 \mathrm{~mL}$ 씩 첨가하여 $37^{\circ} \mathrm{C}$ 의 진탕 항온수조 에서 10 분간 예비 반응시켰다. 이 반응물에 $\alpha$-glucosidase $(10$ $\mathrm{U} / \mathrm{mL}$ ) 효소용액을 동량 첨가하고, 다시 $37^{\circ} \mathrm{C}$ 에서 10 분간 효 소반응을 유도하였다. 반응 후 $\mathrm{Na}_{2} \mathrm{CO}_{3}(100 \mathrm{mM})$ 용액 0.75 $\mathrm{mL}$ 를 첨가하여 반응을 종료시킨 뒤 $420 \mathrm{~nm}$ 에서 흡광도 값 을 측정하였다.

Pancreatic lipase 저해활성은 각 추출물과 pancreatic lipase 효소용액 $(10 \mathrm{U} / \mathrm{mL}) 0.05 \mathrm{~mL}$ 를 시험관에 취하고, 여기에 200 $\mathrm{mM}$ sodium phosphate buffer(pH 7.0) $0.05 \mathrm{~mL}$ 를 추가하여 진탕항온수조 $\left(37^{\circ} \mathrm{C}\right)$ 에서 10 분간 예비반응을 시켰다. 예비반 응 후 $200 \mathrm{mM}$ sodium phosphate buffer(pH 7.0)에 용해된 $p-\mathrm{NPB}(5 \mathrm{mM})$ 기질을 $0.1 \mathrm{~mL}$ 를 첨가한 후 동일하게 $37^{\circ} \mathrm{C}$ 에 서 본 반응시키고 $\mathrm{Na}_{2} \mathrm{CO}_{3}(100 \mathrm{mM}) 0.75 \mathrm{~mL}$ 를 첨가하여 반 응 종료와 함께 $420 \mathrm{~nm}$ 에서 흡광도를 측정하였다. 한편, 모 든 라디칼 및 소화효소 저해활성은 각 추출물 대신 증류수를 사용하여 첨가구와 음성 대조구간의 흡광도 차이를 아래의 식에 대입하여 백분율(\%)로 나타내었다.

활성저해도 $(\%)=(1-$ 음성대조구 / 첨가구 흡광도 $) \times 100$

\section{통계처리}

각 실험은 삼 반복 수행하였으며, 본 결과는 평균 \pm 표준편 차로 나타내었다.

\section{결과 및 고찰}

\section{발효 시간에 따른 콩-분말 두유의 이화학적 특성 변화}

발효 시간에 따른 두유의 이화학적 특성 변화는 Table 1과 같았다. 발효 초기 $\mathrm{pH}$ 는 5.84로 나타났고, 12시간(4.72), 24시
간(4.57), 36시간(4.22) 및 48시간(4.17)까지는 점차적으로 감 소하였고, 이후에는 각각 4.24 및 4.25 로 약간 증가하는 경향 이었다. 산도는 발효 초기 $0.48 \%$ 에서 발효 48 시간째 $1.60 \%$ 로 꾸준히 증가하는 결과를 나타내었으며, $\mathrm{pH}$ 가 증가한 시점 인 발효 60 시간부터 72 시간째에는 각각 $1.32 \%$ 로 약간 감소 하는 경향을 나타내었다(Table 1). 생균수는 발효 초기(5.76 $\log \mathrm{CFU} / \mathrm{mL})$ 부터 발효 36시간 $(7.36 \log \mathrm{CFU} / \mathrm{mL})$ 까지는 $L$. plantarum P1201 균수가 꾸준히 증가하였고, 발효 48시간부 터 72시간까지는 P1201 균수가 조금씩 감소함에 따라 $L$. brevis WCP02 균수가 $6.33 \log \mathrm{CFU} / \mathrm{mL}$ 에서 $8.54 \log$ $\mathrm{CFU} / \mathrm{mL}$ 로 증가하는 경향을 나타내었으며, 총 균수는 발효 과정 중 꾸준히 증가하였다.

전형적인 젖산 발효에서는 $\mathrm{pH}$ 가 감소하고 이에 상응하여 산도가 증가한다. 이 결과는 본 연구와 유사한 콩 젖산 발효 연구에서도 $\mathrm{pH}$ 감소에 따라 산도가 증가하는 결과가 보고되 었다(Lee 등, 2018a; Lee 등, 2018b).

\section{발효 시간에 따른 콩-분말 두유의 유리아미노산 함량 변화}

발효 중 유리아미노산 분석 결과는 Table 2 및 Fig. 1과 같았다. 발효 전 기간에 걸쳐 비필수아미노산의 총 함량은 발 효초기 $623.24 \mathrm{mg} / 100 \mathrm{~g}$ 에서 발효 72시간째 $1102.75 \mathrm{mg} / 100$ $\mathrm{g}$ 으로 크게 증가하였다. 이 중 aspartic $\operatorname{acid}(12.61 \rightarrow 30.26$ $\mathrm{mg} / 100 \mathrm{~g})$, serine $(28.32 \rightarrow 108.99 \mathrm{mg} / 100 \mathrm{~g})$, aminoadipic $\operatorname{acid}(7.31 \rightarrow 87.82 \mathrm{mg} / 100 \mathrm{~g})$, glycine $(15.08 \rightarrow 75.29 \mathrm{mg} / 100$ $\mathrm{g})$, alanine $(83.14 \rightarrow 123.01 \mathrm{mg} / 100 \mathrm{~g}), \alpha$-aminobutyric acid $(3.06 \rightarrow 9.16 \mathrm{mg} / 100 \mathrm{~g})$, cystathionine $(5.31 \rightarrow 10.88 \mathrm{mg} / 100$ g), $\beta$-alanine $(32.43 \rightarrow 37.99 \mathrm{mg} / 100 \mathrm{~g}), \beta$-aminobutyric $\operatorname{acid}(45.37 \rightarrow 74.29 \mathrm{mg} / 100 \mathrm{~g})$, hydroxylproline $(16.34 \rightarrow$ $27.26 \mathrm{mg} / 100 \mathrm{~g})$ 및 anserine $(6.88 \rightarrow 14.33 \mathrm{mg} / 100 \mathrm{~g})$ 은 발

Table 1. Changes in pH, acidity, and viable cell numbers during fermentation of soy-powder milk by mixtures of probiotics $L$. brevis WCP02 and L. plantrum P1201

\begin{tabular}{|c|c|c|c|c|c|c|c|}
\hline \multirow{2}{*}{ Index } & \multicolumn{7}{|c|}{ Fermentation time $(\mathrm{h})$} \\
\hline & 0 & 12 & 24 & 36 & 48 & 60 & 72 \\
\hline \multicolumn{8}{|l|}{ Physiochemical properties } \\
\hline $\mathrm{pH}$ & $5.84 \pm 0.29^{1)}$ & $4.72 \pm 0.24$ & $4.57 \pm 0.23$ & $4.22 \pm 0.21$ & $4.17 \pm 0.21$ & $4.24 \pm 0.21$ & $4.25 \pm 0.21$ \\
\hline Acidity (\%, as lactic acid) & $0.48 \pm 0.02$ & $1.08 \pm 0.05$ & $1.13 \pm 0.06$ & $1.34 \pm 0.07$ & $1.60 \pm 0.08$ & $1.32 \pm 0.07$ & $1.32 \pm 0.07$ \\
\hline \multicolumn{8}{|c|}{ Viable cell numbers $(\log \mathrm{CFU} / \mathrm{mL})$} \\
\hline L. brevis & $4.48 \pm 0.22$ & $3.12 \pm 0.16$ & $3.74 \pm 0.19$ & $4.26 \pm 0.21$ & $6.33 \pm 0.32$ & $8.26 \pm 0.41$ & $8.54 \pm 0.43$ \\
\hline L. plantarum & $5.76 \pm 0.29$ & $7.36 \pm 0.37$ & $7.77 \pm 0.39$ & $7.36 \pm 0.37$ & $5.37 \pm 0.27$ & $3.75 \pm 0.19$ & $4.25 \pm 0.21$ \\
\hline Total & 10.24 & 10.48 & 11.51 & 11.62 & 11.70 & 12.01 & 12.79 \\
\hline
\end{tabular}

\footnotetext{
${ }^{1)}$ All values are represented as the mean $\pm \mathrm{SD}$ of triplicate determination.
} 
Table 2. Changes in free amino acid contents during fermentation of soy-powder milk by mixtures of probiotics $L$. brevis WCP02 and L. plantrum P1201

\begin{tabular}{|c|c|c|c|c|c|c|c|}
\hline \multirow{2}{*}{$\begin{array}{l}\text { Contents } \\
\left(\mathrm{mg} / 100 \mathrm{~g} \mathrm{dw}^{1)}\right)\end{array}$} & \multicolumn{7}{|c|}{ Fermentation time (h) } \\
\hline & 0 & 12 & 24 & 36 & 48 & 60 & 72 \\
\hline \multicolumn{8}{|l|}{ Non-essential amino acids } \\
\hline Glutamic acid & $100.38 \pm 5.02^{2)}$ & $234.88 \pm 11.74$ & $290.13 \pm 14.51$ & $271.86 \pm 13.59$ & $236.79 \pm 11.84$ & $182.48 \pm 9.12$ & $177.91 \pm 8.91$ \\
\hline$\gamma$-Aminobutyric acid & $32.05 \pm 1.61$ & $47.20 \pm 2.36$ & $65.30 \pm 3.27$ & $75.72 \pm 3.79$ & $82.53 \pm 4.13$ & $83.22 \pm 4.16$ & $76.22 \pm 3.81$ \\
\hline Aspartic acid & $12.61 \pm 0.63$ & $31.51 \pm 1.58$ & $32.68 \pm 1.63$ & $13.81 \pm 0.69$ & $8.25 \pm 0.41$ & $26.38 \pm 1.32$ & $30.26 \pm 1.51$ \\
\hline Serine & $28.32 \pm 1.42$ & $86.15 \pm 4.31$ & $117.31 \pm 5.87$ & $107.24 \pm 5.36$ & $55.37 \pm 2.77$ & $83.14 \pm 4.16$ & $108.99 \pm 5.45$ \\
\hline Aminoadipic acid & $7.31 \pm 0.37$ & $26.71 \pm 1.34$ & $51.01 \pm 2.55$ & $72.42 \pm 3.62$ & $58.34 \pm 2.92$ & $55.15 \pm 2.76$ & $87.82 \pm 4.39$ \\
\hline Glycine & $15.08 \pm 0.75$ & $61.98 \pm 3.11$ & $79.11 \pm 3.96$ & $77.08 \pm 3.85$ & $40.25 \pm 2.01$ & $57.33 \pm 2.87$ & $75.29 \pm 3.76$ \\
\hline Alanine & $83.14 \pm 4.16$ & $141.45 \pm 7.07$ & $159.47 \pm 7.97$ & $117.63 \pm 5.88$ & $72.60 \pm 3.63$ & $99.38 \pm 4.97$ & $123.01 \pm 6.15$ \\
\hline Cystathionine & $5.31 \pm 0.27$ & $8.90 \pm 0.45$ & $8.51 \pm 0.43$ & $8.02 \pm 0.41$ & $4.71 \pm 0.24$ & $7.64 \pm 0.38$ & $10.88 \pm 0.54$ \\
\hline Tyrosine & $26.95 \pm 1.35$ & $21.50 \pm 1.08$ & $8.22 \pm 0.41$ & $9.06 \pm 0.45$ & $5.85 \pm 0.29$ & $9.46 \pm 0.47$ & $12.99 \pm 0.65$ \\
\hline$\beta$-Alanine & $32.43 \pm 1.62$ & $73.58 \pm 3.68$ & $87.06 \pm 4.35$ & $80.70 \pm 4.04$ & $49.59 \pm 2.48$ & $33.19 \pm 1.66$ & $37.99 \pm 1.91$ \\
\hline Aminoethanol & $4.92 \pm 0.25$ & $6.22 \pm 0.31$ & $7.71 \pm 0.39$ & $6.90 \pm 0.35$ & $5.29 \pm 0.26$ & $7.53 \pm 0.38$ & $7.35 \pm 0.37$ \\
\hline Hydroxyproline & $16.34 \pm 0.82$ & $12.50 \pm 0.63$ & $17.02 \pm 0.85$ & $16.00 \pm 0.80$ & $2.12 \pm 0.11$ & $23.23 \pm 1.16$ & $27.26 \pm 1.36$ \\
\hline Ornithine & $2.46 \pm 0.12$ & $193.72 \pm 9.69$ & $233.48 \pm 11.67$ & $217.50 \pm 10.88$ & $126.26 \pm 6.31$ & $179.51 \pm 8.98$ & $215.45 \pm 10.77$ \\
\hline Anserine & $6.88 \pm 0.34$ & $10.37 \pm 0.52$ & $9.93 \pm 0.50$ & $11.84 \pm 0.59$ & $5.09 \pm 0.25$ & $13.78 \pm 0.69$ & $14.33 \pm 0.72$ \\
\hline Carnosine & $\mathrm{ND}^{3)}$ & $41.85 \pm 2.09$ & $30.89 \pm 1.54$ & $75.03 \pm 3.75$ & $7.85 \pm 0.39$ & $9.07 \pm 0.45$ & $10.83 \pm 0.54$ \\
\hline Arginine & $153.13 \pm 7.66$ & ND & $2.39 \pm 0.12$ & $5.98 \pm 0.30$ & $1.64 \pm 0.08$ & $2.32 \pm 0.12$ & $2.72 \pm 0.14$ \\
\hline Total & 527.31 & 998.523 & $1,200.22$ & $1,166.79$ & 762.53 & 872.81 & $1,019.30$ \\
\hline \multicolumn{8}{|l|}{ Essential amino acids } \\
\hline Threonine & $0.93 \pm 0.05$ & $3.91 \pm 0.21$ & $69.66 \pm 3.48$ & $54.37 \pm 2.72$ & $28.69 \pm 1.43$ & $43.14 \pm 2.16$ & $58.76 \pm 2.94$ \\
\hline Valine & $26.11 \pm 1.31$ & $86.40 \pm 4.32$ & $93.82 \pm 4.69$ & $76.27 \pm 3.81$ & $38.40 \pm 1.92$ & $55.71 \pm 2.79$ & $77.17 \pm 3.86$ \\
\hline Methionine & $14.40 \pm 0.72$ & $27.74 \pm 1.39$ & $30.53 \pm 1.53$ & $24.19 \pm 1.21$ & $12.78 \pm 0.64$ & $18.91 \pm 0.95$ & $26.34 \pm 1.32$ \\
\hline Isoleucine & $24.01 \pm 1.21$ & $48.54 \pm 2.43$ & $55.96 \pm 2.81$ & $43.95 \pm 2.20$ & $17.07 \pm 0.85$ & $26.12 \pm 1.31$ & $40.39 \pm 2.02$ \\
\hline Leucine & $49.19 \pm 2.46$ & $139.14 \pm 6.96$ & $181.81 \pm 9.09$ & $161.10 \pm 8.06$ & $69.49 \pm 3.47$ & $98.96 \pm 4.95$ & $144.33 \pm 7.22$ \\
\hline Phenylalanine & $44.93 \pm 2.25$ & $120.31 \pm 6.02$ & $162.21 \pm 8.11$ & $137.90 \pm 6.90$ & $69.04 \pm 3.45$ & $93.18 \pm 4.66$ & $128.90 \pm 6.45$ \\
\hline Lysine & $36.93 \pm 1.85$ & $77.44 \pm 3.87$ & $89.32 \pm 4.47$ & $76.08 \pm 3.80$ & $48.09 \pm 2.41$ & $59.61 \pm 2.98$ & $77.21 \pm 3.86$ \\
\hline Histidine & $14.63 \pm 0.73$ & $29.72 \pm 1.49$ & $39.21 \pm 1.96$ & $36.14 \pm 1.81$ & $23.29 \pm 1.16$ & $29.54 \pm 1.48$ & $36.00 \pm 1.81$ \\
\hline Total & 211.13 & 533.2 & 722.52 & 610.0 & 306.85 & 425.17 & 589.1 \\
\hline Total amino acids & 738.44 & $1,531.72$ & $1,922.74$ & $1,776.79$ & $1,069.38$ & $1,297.98$ & $1,608.4$ \\
\hline Ammonia & $19.61 \pm 0.98$ & $34.84 \pm 1.74$ & $42.19 \pm 2.11$ & $40.48 \pm 2.02$ & $26.69 \pm 1.33$ & $25.84 \pm 1.29$ & $48.61 \pm 2.43$ \\
\hline
\end{tabular}

${ }^{1)} \mathrm{dw}$, dry weight.

${ }^{2)}$ All values are represented as the mean $\pm \mathrm{SD}$ of triplicate determination.

${ }^{3)} \mathrm{ND}$, not detected. 

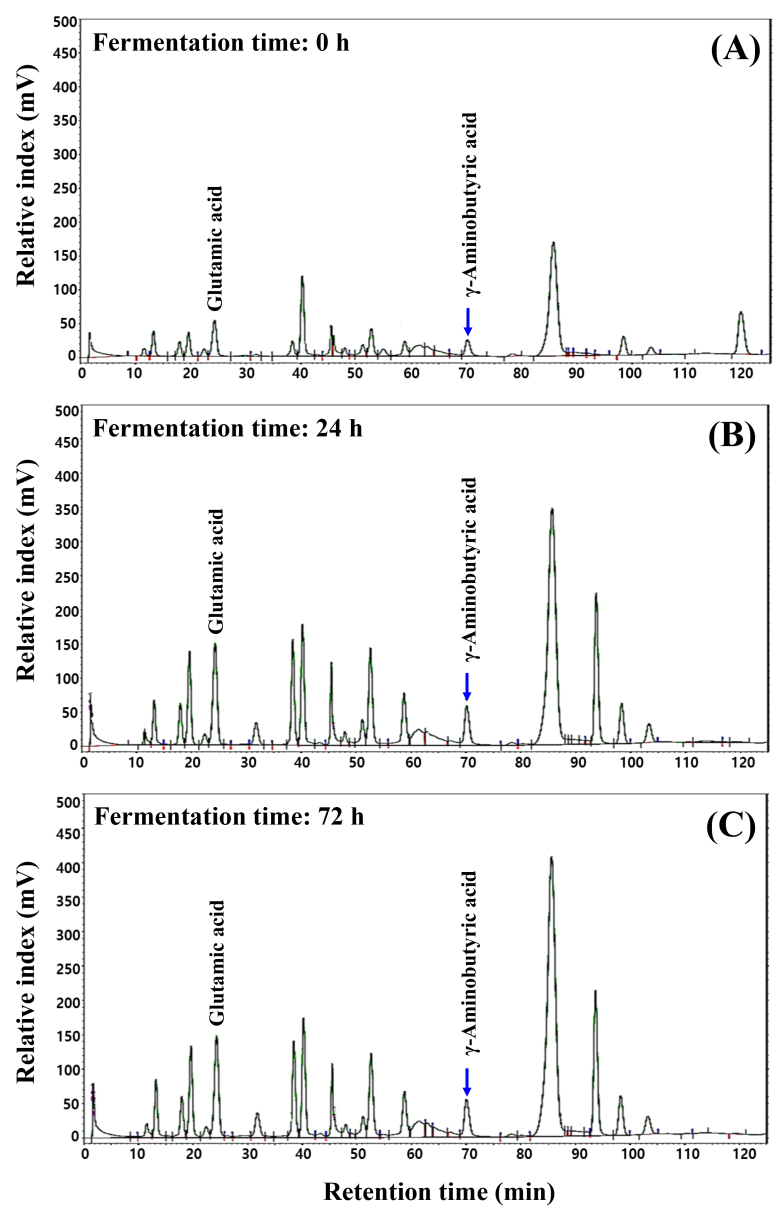

Fig. 1. Changes in free amino acid chromatogram during fermentation of soy-powder milk by mixtures of probiotics $L$. brevis WCP02 and L. plantrum P1201.

효 초기보다 발효 72시간째 크게 증가하였다. 특히 ornithine 의 경우 발효 초기 $2.46 \mathrm{mg} / 100 \mathrm{~g}$ 에서 발효 72시간째 21.45 $\mathrm{mg} / 100 \mathrm{~g}$ 으로 비필수아미노산 중 가장 큰 증가폭을 나타내 었다(Table 2). 필수아미노산인 threonine $(0.93 \rightarrow 58.76$ $\mathrm{mg} / 100 \mathrm{~g})$, valine $(26.11 \rightarrow 77.17 \mathrm{mg} / 100 \mathrm{~g})$, methionine $(14.40 \rightarrow 26.34 \mathrm{mg} / 100 \mathrm{~g})$, isoleucine $(24.01 \rightarrow 40.39 \mathrm{mg} / 100$ $\mathrm{g})$, phenylalanine $(44.93 \rightarrow 128.90 \mathrm{mg} / 100 \mathrm{~g})$, lysine $(36.93$ $\rightarrow 77.21 \mathrm{mg} / 100 \mathrm{~g})$ 및 histidine $(14.63 \rightarrow 36.00 \mathrm{mg} / 100 \mathrm{~g})$ 역시 발효 72시간째 모두 증가하였으며 특히 leucine은 49.19 $\mathrm{mg} / 100 \mathrm{~g}$ 에서 $144.33 \mathrm{mg} / 100 \mathrm{~g}$ 으로 가장 큰 증가폭을 나타 내었다(Table 2). 한편, 발효 초기 glutamic acid와 $\gamma$ -aminobutyric acid는 각각 23 분과 70 분대에 검출되었고(Fig. 1A) 발효 초기 glutamic acid 함량은 $100.38 \mathrm{mg} / 100 \mathrm{~g}$ 에서 발효 12 시간 $(234.88 \mathrm{mg} / 100 \mathrm{~g})$ 과 발효 24시간째 290.13 $\mathrm{mg} / 100 \mathrm{~g}$ 으로 가장 많이 증가하였고(Fig. 1B), 발효 36시간 부터 $271.86 \mathrm{mg} / 100 \mathrm{~g}$ 으로 감소하였고, 발효 48시간(236.79 $\mathrm{mg} / 100 \mathrm{~g}), 60$ 시간 $(182.48 \mathrm{mg} / 100 \mathrm{~g}), 72$ 시간 $(177.91 \mathrm{mg} / 100$ $\mathrm{g}$ )에 걸쳐 glutamic acid 함량은 서서히 감소하였다. GABA 함량은 조금씩 증가하여 발효 초기 $32.05 \mathrm{mg} / 100 \mathrm{~g}$ 에서 발효 12 시간 $(47.20 \mathrm{mg} / 100 \mathrm{~g})$, 발효 24시간 $(65.30 \mathrm{mg} / 100 \mathrm{~g})$, 발 효 36시간 $(75.72 \mathrm{mg} / 100 \mathrm{~g})$, 발효 48시간 $(82.53 \mathrm{mg} / 100 \mathrm{~g})$, 발효 60 시간째 $83.22 \mathrm{mg} / 100 \mathrm{~g}$ 으로 크게 증가하였고, 발효 72시간째에는 $76.22 \mathrm{mg} / 100 \mathrm{~g}$ 으로 약간 감소하였다(Fig. 1C).

발효 과정 중 특정 유리아미노산이 증가하는 결과는 Baumann 등(1991)의 곰팡이를 이용한 템페 발효 연구 결과 와 일치하였다. Pyo(2008) 역시 본 연구와 유사한 형태의 홍 국균을 이용한 콩 발효 과정 중 유리아미노산 총 함량이 $2,936.2 \mathrm{mg} / 100 \mathrm{~g}$ 으로 증가함을 보고하였으며, 본 연구와도 유사하였다. 특히 Pyo(2008)는 발효콩은 비 발효 콩에 비해 arginine 함량은 감소한다고 하였고, lysine, leucine, phenylananine과 같은 필수아미노산은 증가한다고 보고하였고, 이 같은 결과는 본 연구 결과와도 일치하였다. Kamiya(2002)와 Aoyama 등(1996)의 결과에 따르면 유리아미노산 강화는 기 존에 알려진 감칠맛 부여뿐만 아니라, 흡수 촉진(Aoyama 등, 1996) 및 항산화(Hoppe 등, 1997)와 같은 몇몇 영양학적 장 점을 보고하였다. 따라서 본 연구에서 제조한 발효두유는 비 배당체 isoflavone뿐만 아니라, GABA와 여러 유리아미노산 들이 풍부하므로 이미 알려진 항고혈압(Hwang 등, 2018c)과 같은 약리학적 효과들이 잠재적으로 내재되어 있을 것으로 기대된다.

\section{발효 시간에 따른 콩-분말 두유의 isoflavone 함량 변화}

발효 시간에 따른 두유의 isoflavone 함량 분석 결과는 Table 3, HPLC 크로마토그램 변화는 Fig. 2에 나타내었다. 총 6종류의 유도체가 검출되었고, 발효 초기에는 daidzin(peak 1), glycitin(peak 2), genistin(peak 3)이 주요 isoflavone 화합 물로 나타났으며(Fig. 2A,B), 발효 기간이 증가할수록 서서 히 감소하였고, 발효 60시간째에는 daidzin(peak 1), glycitin (peak 2), genistin(peak 3)은 발효 초기에 비해 크게 감소하였 다. 발효 72시간째에는 daidzein(peak 4), glycitein(peak 5), genistein(peak 6)과 같은 비배당체 isoflavone이 크게 증가하 는 양상을 나타내었다(Fig. 2C). 발효 초기 배당체 isoflavone 총합은 $1,910.47 \mu \mathrm{g} / \mathrm{g}$ 이 검출되었고, 발효 12 시간째에는 $1,586.67 \mu \mathrm{g} / \mathrm{g}$ 으로 약간 감소하였으며, 발효 24시간째에는 $664.34 \mu \mathrm{g} / \mathrm{g}$ 으로 거의 대부분 감소하였다. 이후에도 지속적 으로 감소하였으며, 발효 72 시간째에는 $110.12 \mu \mathrm{g} / \mathrm{g}$ 이 검출 되었다. 이에 상응하여 비배당체 isoflavone은 꾸준히 증가하 는 경향을 나타내었고, 발효 12시간째 $453.89 \mu \mathrm{g} / \mathrm{g}$, 발효 24시 간째 $787.73 \mu \mathrm{g} / \mathrm{g}$, 발효 36시간째 비배당체 총 함량은 $1,216.62$ 
Table 3. Changes in isoflavone contents and conversion rate during fermentation of soy-powder milk by mixtures of probiotics $L$. brevis WCP02 and L. plantrum P1201

\begin{tabular}{|c|c|c|c|c|c|c|c|}
\hline \multirow{2}{*}{$\begin{array}{l}\text { Contents } \\
\left(\mu \mathrm{g} / \mathrm{g} \mathrm{dw}^{1)}\right)\end{array}$} & \multicolumn{7}{|c|}{ Fermentation time (h) } \\
\hline & 0 & 12 & 24 & 36 & 48 & 60 & 72 \\
\hline \multicolumn{8}{|l|}{ Glycosides } \\
\hline Daidzin & $746.23 \pm 37.31^{2)}$ & $842.95 \pm 42.15$ & $452.07 \pm 22.60$ & $23.69 \pm 1.18$ & $21.41 \pm 1.07$ & $22.02 \pm 1.10$ & $24.04 \pm 1.20$ \\
\hline Glycitin & $183.52 \pm 9.18$ & $207.70 \pm 10.39$ & $136.00 \pm 6.80$ & $94.21 \pm 4.71$ & $72.17 \pm 3.61$ & $71.55 \pm 3.58$ & $76.00 \pm 3.80$ \\
\hline Genistin & $980.72 \pm 49.04$ & $536.02 \pm 26.80$ & $76.27 \pm 3.81$ & $12.45 \pm 0.62$ & $8.40 \pm 0.42$ & $8.95 \pm 0.45$ & $10.08 \pm 0.50$ \\
\hline Total & $1,910.47$ & $1,586.67$ & 664.34 & 130.35 & 101.98 & 102.52 & 110.12 \\
\hline Ratio (\%) & 94.86 & 77.76 & 45.75 & 9.68 & 9.00 & 8.53 & 9.06 \\
\hline \multicolumn{8}{|l|}{ Aglycones } \\
\hline Daidzein & $52.03 \pm 2.60$ & $158.95 \pm 7.95$ & $329.29 \pm 16.46$ & $653.41 \pm 32.67$ & $533.52 \pm 26.68$ & $565.37 \pm 28.27$ & $577.01 \pm 28.85$ \\
\hline Glycitein & $12.95 \pm 0.65$ & $21.51 \pm 1.08$ & $38.91 \pm 1.95$ & $57.20 \pm 2.86$ & $61.69 \pm 3.08$ & $67.33 \pm 3.37$ & $66.48 \pm 3.32$ \\
\hline Genistein & $38.62 \pm 1.93$ & $273.43 \pm 13.67$ & $419.53 \pm 20.98$ & $506.01 \pm 25.30$ & $436.30 \pm 21.82$ & $466.83 \pm 23.34$ & $462.42 \pm 23.12$ \\
\hline Total & 103.60 & 453.89 & 787.73 & $1,216.62$ & $1,031.51$ & $1,099.53$ & $1,105.91$ \\
\hline Ratio (\%) & 5.14 & 22.24 & 54.25 & 90.32 & 91.00 & 91.47 & 90.94 \\
\hline Total isoflavones & $2,014.07$ & $2,040.56$ & $1,452.07$ & $1,346.97$ & $1,133.49$ & $1,202.05$ & $1,216.03$ \\
\hline
\end{tabular}

1) dw, dry weight.

${ }^{2)}$ All values are represented as the mean $\pm \mathrm{SD}$ of triplicate determination.

$\mu \mathrm{g} / \mathrm{g}$ 으로 가장 크게 증가하였고(Table 3 및 Fig. 2B), 이때 배당체로부터 비배당체로의 전환율은 $90.32 \%$ 로 나타났다. 한편, 발효 $48(1,031.51 \mu \mathrm{g} / \mathrm{g})$ 및 60 시간 $(1,099.53 \mu \mathrm{g} / \mathrm{g})$ 에는 비배당체 총 함량이 약간 감소하는 결과를 나타내었으나, 배 당체 isoflavone 함량이 감소함에 따라 전환율은 91.00 및 $91.47 \%$ 로 좀 더 우수하였고, 발효 72시간에는 $1,105.91 \mu \mathrm{g} / \mathrm{g}$ 으로 약간 증가하였고, 배당체로부터 비배당체 isoflavone 전 환율은 최종적으로 $90.94 \%$ 를 나타내었다. 또한, isoflavone 총 함량은 발효 초기 $(2,014.07 \mu \mathrm{g} / \mathrm{g})$ 에서 발효 종료 $(1,216.03$ $\mu \mathrm{g} / \mathrm{g}$ ) 시점이 될수록 감소하는 경향을 나타내었다(Table 3).

Yang 등(2013)은 B. subtilis(고초균)와 L. plantarum(유산 균)을 이용하여 토마토 추출액 첨가 콩 요구르트를 제조하고, 발효시킨 결과는 본 연구 결과와도 마찬가지로 배당체는 감 소하고 비배당체는 증가한다고 하였다. 이와 유사한 식품인 청국장의 경우 역시 발효 초기보다 발효 후기에 비배당체 isoflavone이 증가한다는 것이 이미 보고되었다(Cho 등, 2009; Cho 등, 2011). 또한, 일반적으로 콩의 경우 발효 과정 중이나 열처리와 같은 물리적 처리 시에 phenolics 화합물이 추출된다고 보고되었으며, 특히 flavonoid 계열의 daidzein과 genistein이 가장 대표적인 화합물로 알려져 있다(Pratt 등, 1981). 한편, Jeong 등(2005)은 콩을 산 가수분해 시 daidzein
및 genistein 함량이 증가함을 보고하였으며, 특히 두류 식품 에서 배당체 isoflavone 감소가 일어나는 동시에 비배당체 isoflavone이 증가하는 현상은 유산균과 같은 발효 미생물들 이 생성하는 젖산, 아세톤 등의 대사물질에 의해 결합한 당들 의 분리가 이루어지고, 이들이 생성하는 $\beta$-glucosidase 활성 즉, 생물 전환에 따른 것으로 여러 연구에서 보고되었다 (Hwang 등, 2016a; Hwang 등, 2016b; Lee 등, 2018a; Lee 등, 2018b; Cho 등, 2018). 특히 본 연구에서 사용한 유산균과 유사한 유산균주들을 콩 발효에 적용하였을 시 Lactobacillus acidophilus는 비배당체 isoflavone 전환율이 $63 \%$ 였고, Lactobacillus casei는 77\%의 전환율을 나타내어 본 연구 결 과와도 유사하다고 판단된다(Donkor와 Shah, 2008).

\section{발효 시간에 따른 콩-분말 두유의 항산화 활성 및 소화 효소 저해활성 변화}

발효 시간에 따른 두유의 라디칼 소거활성과 소화효소 저 해활성 변화는 Table 4 와 같았다. DPPH 라디칼 소거활성 측 정 결과, 발효 초기에는 $30.23 \%$ 의 소거활성을 보였고, 발효 24시간까지는 소거활성의 변화가 크게 없었으며, 발효 36시 간(43.51\%)에서 발효 48시간(61.47\%)까지는 서서히 증가하 였고, 발효 60시간과 72 시간째에 각각 $88.03 \%$ 및 $88.50 \%$ 로 

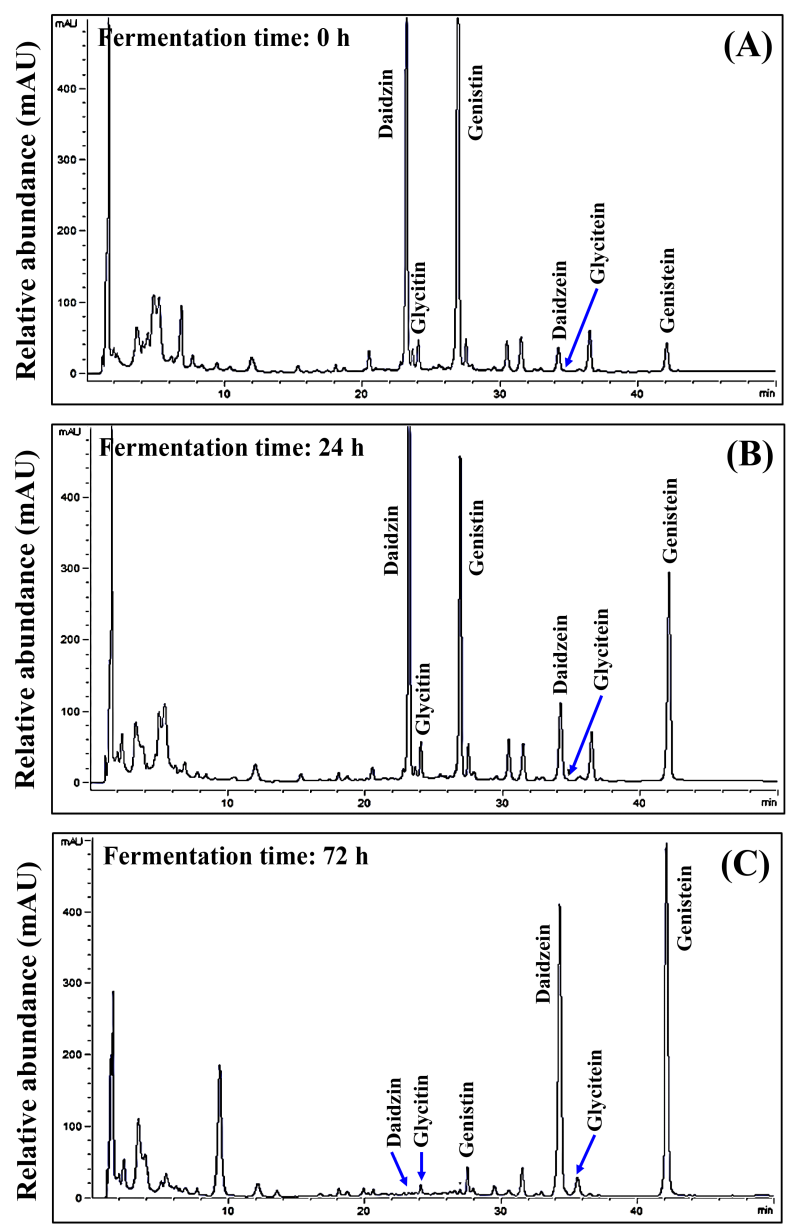

Retention time (min)

Fig. 2. Changes in isoflavones on HPLC chromatogram during fermentation of soy-powder milk by mixtures of probiotics $L$. brevis WCP02 and L. plantrum P1201.
가장 크게 증가하였다. ABTS 라디칼 소거활성은 발효 초기 $59.71 \%$ 에서 발효 72 시간째 $74.54 \%$ 를 나타냄으로써 DPPH 와는 다르게 발효 과정 중 서서히 증가하는 결과를 나타내었 다. Hydroxyl 라디칼 역시 ABTS와 일치하는 결과를 나타내 었으며, 발효 초기 $65.51 \%$ 의 우수한 소거활성을 나타내었고, 발효 과정 중 서서히 증가하여 72 시간째에는 $76.10 \%$ 를 나타 내었다.

발효가 진행됨에 따라 모든 라디칼 소거활성이 증가하는 결과는 발효 과정 중 생성되는 total phenolics 및 비배당체 isoflavone 함량과 관련이 있는 것으로 판단된다(Kim 등, 2000). Chung 등(2011)은 원료 콩 및 콩 품종별 청국장의 비 교 연구에서 phenolic 및 isoflavone 화합물 함량에 비례하여 항산화 활성이 증가함을 보고하였다. 또한, 콩이 아닌 다른 작물인 옥수수를 볶음처리하였을 경우, 갈변반응에 의해 phenolics 화합물이 생성되고, 이 결과 항산화 활성이 증가한 다고 Youn과 Chung(2012) 및 Durmaz와 Alpaslan(2007)은 보고하였다. 이렇듯 phenolics와 비배당체 isoflavone 화합물 들은 항산화 활성에 크게 기여하는 것으로 사료된다.

한편, $\alpha$-glucosidase(탄수화물 분해) 저해활성은 발효 초기 $12.38 \%$ 의 아주 낮게 나타났고, 발효 12 시간째 $18.43 \%$ 로 약간 증가하였으며, 발효가 진행됨에 따라 $31.97 \%, 36.28 \%, 40.05 \%$, $43.62 \%, 45.38 \%$ 로 각각 증가하였다. 한편, 발효 24시간까지 는 pancreatic lipase 저해활성이 8-11.28\%로 큰 차이를 보이 지 않았으나, 24시간째부터 $17.07 \%$ 로 조금 증가하였고 발효 과정 중 서서히 증가하여 72 시간째에는 $34.53 \%$ 의 저해 활성 을 나타내었다.

$\alpha$-Glucosidase는 소장점막에 존재하는 효소이며, 식품 섭 취 시 탄수화물을 포도당 단위의 단당류로 분해하는 기능을 하므로 소화와 흡수에 필수적이다. 이 탄수화물 효소 활성을

Table 4. Changes in antioxidant and enzyme inhibitory effects during fermentation of soy-powder milk by mixtures of probiotics $L$. brevis WCP02 and L. plantrum P1201

\begin{tabular}{|c|c|c|c|c|c|c|c|}
\hline \multirow{2}{*}{ Activities $(\%)$} & \multicolumn{7}{|c|}{ Fermentation time $(\mathrm{h})$} \\
\hline & 0 & 12 & 24 & 36 & 48 & 60 & 72 \\
\hline \multicolumn{8}{|c|}{ Scavenging activity against radical (\%) } \\
\hline $\mathrm{DPPH}$ & $30.23 \pm 1.51^{1)}$ & $31.54 \pm 1.58$ & $31.65 \pm 1.58$ & $43.51 \pm 2.18$ & $61.47 \pm 3.07$ & $88.03 \pm 4.40$ & $88.50 \pm 4.43$ \\
\hline ABTS & $59.71 \pm 2.99$ & $60.50 \pm 3.03$ & $63.12 \pm 3.16$ & $66.54 \pm 3.33$ & $69.69 \pm 3.48$ & $73.49 \pm 3.67$ & $74.54 \pm 3.73$ \\
\hline Hydroxyl & $65.51 \pm 3.28$ & $66.44 \pm 3.32$ & $66.84 \pm 3.34$ & $68.31 \pm 3.42$ & $69.44 \pm 3.47$ & $71.97 \pm 3.60$ & $76.10 \pm 3.81$ \\
\hline \multicolumn{8}{|c|}{ Inhibitory activity against enzyme (\%) } \\
\hline$\alpha$-Glucosidase & $12.38 \pm 0.62$ & $18.43 \pm 0.92$ & $31.97 \pm 1.60$ & $36.28 \pm 1.81$ & $40.05 \pm 2.00$ & $43.62 \pm 2.18$ & $45.38 \pm 2.27$ \\
\hline Pancreatic lipase & $8.00 \pm 0.40$ & $10.00 \pm 0.50$ & $11.28 \pm 0.56$ & $17.07 \pm 0.85$ & $21.76 \pm 1.09$ & $32.34 \pm 1.62$ & $34.53 \pm 1.73$ \\
\hline
\end{tabular}

\footnotetext{
${ }^{1)}$ All values are represented as the mean $\pm \mathrm{SD}$ of triplicate determination.
} 
저해시킨 결과로는 포도당 흡수 억제에 따른 혈당상승을 감소 시킬 수 있어 당뇨 치료제로도 사용되고 있다(Lee 등, 2014). 또한, 일반적으로 당 대사에 따라 산소의 증가가 일어나는데, 이는 생체 내 활성산소를 유발한다고 알려져 있어(Kim과 Yoon, 2014) 이와 같은 혈당 상승 저해는 잠재적으로 산화적 스트레스 개선 효과 또한 있을 것으로 기대된다. 한편, lipase 는 췌장에서 생성되는 효소 중 하나로써 중성지방을 소화하 는데 도움을 주는 효소이다. 그러나 지방 함량이 많은 식품을 과다 섭취하였을 시에는 인체에 흡수된 지방산은 triglyceride 로 재합성되고, 과다 존재 시 인체 여러 조직에 축적되며 체중 이 증가하게 된다. 지방 분해와 흡수에 중요한 역할을 하는 lipase 활성을 저해시킨다면 지방이 축적되지 않고 체외로 배설 됨으로써 대사증후군과 같은 성인병을 예방할 수 있다(Kwon 등, 2014). Park(2013)은 보통 천연 식물들은 poly phenol을 함 유하고 있으며, 이들 추출물은 지방세포의 분해를 억제하고, 그 결과 지질 축적을 감소시킨다고 보고하였다. $\mathrm{Kim}$ 등(2000) 은 21종류의 flavonoid 화합물에 대해 $\alpha$-glucosidase 저해활 성을 물질을 탐색한 결과, luteolin, amentoflavone, luteolin 7-O-glucoside, daidzein, genistein 순서로 저해활성 효과를 나타낸다고 보고하였다. 특히, Park 등(2009)은 이들 화합물 중 daidzein의 경우 $100 \mu \mathrm{g} / \mathrm{mL}$ 농도에서 약 $80 \%$ 의 우수한 $\alpha$-glucosidase 저해활성이 있음을 보고하였으며, 이 결과로부 터 본 연구에서 제조한 발효두유의 경우에도 daidzein과 같은 다양한 flavonoid 화합물에 기인하여 저해활성이 나타난 것 으로 판단된다. 한편, pancreatic lipase 저해활성의 경우, 대 부분의 천연 식물 추출물에서는 다량의 polyphenol 화합물에 의해 lipase 저해활성을 나타낸다는 Park(2013)의 보고도 있 었다. 한편, $\mathrm{Kim}$ 등(2009)도 혈당과 지방 흡수기전을 저해하 는 물질은 메밀 추출물에서 유래된 flavonoid계 화합물이라 보고하였고, Behloul와 $\mathrm{Wu}(2013)$ 및 Lee 등(2013)도 지방 전 구세포에 daidzein과 genistein 추출물을 반응시켰을 시 혈당과 혈중지질 농도가 감소함을 보고하였다. 이외 Hong 등(2010)의 산양삼 잎으로부터 lipase 저해활성 물질 분리 연구 결과에서 는 flavonoid계 화합물 중 kaempferol-3-O-sophoroside( $\mathrm{IC}_{50}$ value, $20.3 \mu \mathrm{M}$ ), kaempferol( $\left(\mathrm{IC}_{50}\right.$ value, $9.1 \mu \mathrm{M}$ ) 화합물이 lipase 저해활성이 있는 것으로 보고하였다. 따라서 이러한 연구결과들을 종합한 결과, 본 연구에서 제조한 발효두유의 경우 발효 과정에 따라 daidzein 및 genistein이 크게 증가하 였고, 생리활성 물질 중 polyphenol 함량 측정을 하지는 않았 으나 발효 중 유효성분 함량이 증가한다고 기 보고된 다양한 콩 관련 논문에 따라 flavonoid계 화합물들에 의해 효소활성 저해를 나타낸 것으로 판단된다.

끝으로, 복합 유산균으로 발효시킨 두유는 phytochemical 함량과 항산화 활성이 발효시간에 비례적으로 증가하는 경향
을 나타내었다. 특히, GABA와 비배당체 isoflavone 함량과 전 환율이 60 시간까지 꾸준히 증가하였으나, 72 시간째 약간 감소 하는 경향을 나타내었다. 큰 감소폭은 아니나 향후 발효 시간 절약과 유용물질 생성량을 고려한다면, 최적 발효시간은 60시 간으로 조정이 필요할 것으로 판단된다. 그러므로 본 연구에서 사용한 복합 생균제제(L. plantarum P1201 및 L. brevis WCP02)들은 두유 발효가 진행됨에 따라 비배당체 isoflavone 과 $\mathrm{GABA}$ 함량이 동시에 증진되므로 isoflavone에 의한 여성 호르몬 대체재로, GABA에 의한 혈압저하 등의 복합 효능을 나타내는 식품 원료로 활용 가능할 것으로 사료된다.

\section{요 약}

본 연구에서는 Lactobacillus plantarum P1201 및 Lactobacillus brevis WCP02 균주를 사용하여 콩 분말 두유(soy-powder milk, SPM) 발효 시간에 따른 가바 $(\gamma$-aminobutyric acid, $\mathrm{GABA})$ 와 이소플라본 함량 및 항산화 활성 변화를 측정하였 다. 글루탐산 함량은 발효 24시간까지 크게 증가하였으나 $(100.38 \rightarrow 290.13 \mathrm{mg} / 100 \mathrm{~g})$, 발효 72시간 후에는 감소하였 다 $(177.91 \mathrm{mg} / 100 \mathrm{~g})$. 그러나 가바 함량은 콩 분말 두유 발효 중 $32.05 \mathrm{mg} / 100 \mathrm{~g}$ (0시간)에서 $76.22 \mathrm{mg} / 100 \mathrm{~g}$ (72시간)으로 크게 증가하였다. 또한 콩 분말 두유 발효 동안 배당체 이소 플라본인 daidzin $(746.23 \rightarrow 24.04 \mu \mathrm{g} / \mathrm{g})$, glycitin $(183.52 \rightarrow$ $76.00 \mu \mathrm{g} / \mathrm{g})$ 및 genistin $(980.72 \rightarrow 10.08 \mu \mathrm{g} / \mathrm{g})$ 함량은 크게 감소하였으나, 이에 상응하여 비배당체 이소플라본인 daidzein $(52.03 \rightarrow 577.01 \mu \mathrm{g} / \mathrm{g})$, glycitein $(12.95 \rightarrow 66.48 \mu \mathrm{g} / \mathrm{g})$ 및 genistein $(38.62 \rightarrow 462.42 \mu \mathrm{g} / \mathrm{g}$ ) 함량은 크게 증가하였다. 항 산화 활성 및 소화효소 저해 활성 역시 콩 분말 두유 발효 중 크게 증가하였다. 특히, $1 \mathrm{mg} / \mathrm{mL}$ 농도 처리 시 $\mathrm{DPPH}$ $(30.23 \rightarrow 88.50 \%), \operatorname{ABTS}(59.71 \rightarrow 74.54 \%)$ 및 hydroxyl $(65.51 \rightarrow 76.10 \%)$ 라디칼 소거 활성과 pancreatic lipase $(8.00$ $\rightarrow 34.53 \%)$ 와 $\alpha$-glucosidase $(12.38 \rightarrow 45.38 \%)$ 저해 활성이 증가하였다.

\section{감사의 글}

본 연구는 2016년도 교육부와 한국연구재단의 기초연구사 업(No. 2016R1D1A1B01009898)의 지원과 중소벤처기업부 에서 지원하는 2018년도 산학연협력 기술개발사업(No. S26 66938)의 지원에 의해 이루어진 결과입니다.

\section{Conflict of interests}

The authors declare no potential conflict of interest. 


\section{ORCID}

Chung Eun Hwang

https://orcid.org/0000-0002-7130-1818

Kye Man Cho https://orcid.org/0000-0002-5928-0532

\section{References}

An MK, Ahn JB, Lee SH, Lee KG. Analysis of $\gamma$ aminobutyric acid (GABA) content in germinated pigmented rice. Korean J Food Sci Technol, 42, 632-636 (2010)

Aoyama N, Fukui K, Yamamoto T. Effect of various forms of force-fed nitrogen sources on gastric transit time in rats. Nippon Eiyo Shokuryo Gakkaishi, 49, 46-51 (1996)

Baumann U, Bisping B, Rehm HJ. Content and release of amino acids during the fermentation of tempe by several strains of Rhizopus sp. Dechema Biotechnology Conference. Behrens D, Wiley Europe Weinheim, 4, p 205-208 (1991)

Behloul N, Wu G. Genistein: A promising therapeutic agent for obesity and diabetes treatment. Eur J Pharmacol, 698, 31-38 (2013)

Brouns F. Soya isoflavones: A new and promising ingredient for the health foods sector. Food Res Int, 35, 187-193 (2002)

Cha MN, Jun HI, Song GS, Kim YS. The effects of germination conditions on GABA and the nutritional components of barley. Korean J Food Sci Technol, 44, 41-47 (2012)

Cho KM, Hong SY, Math RK, Lee JH, Kambiranda DM, Kim JM, Islam SMA, Yun MG, Cho JJ, Lim WJ, Yun HD. Biotransformation of phenolics (isoflavones, flavanols and phenolic acids) during the fermentation of Cheonggukjang by Bacillus pumilus HY1. Food Chem, 114, 413-419 (2009)

Cho KM, Hwang CE, Kim SC, Joo OS. Physicochemical properties, phytochemicals, and biological activities of heat-treated Elaegnus multiflora juice and vinegar. Korean J Food Preserv, 25, 52-61 (2018)

Cho KM, Lee JH, Yun HD, Ahn BY, Kim H, Seo WT. Changes of phytochemical constituents (isoflavones, flavanols, and phenolic acids) during Cheonggukjang soybeans fermentation using potential probiotics Bacillus subtilis CS90. J Food Compos Anal, 24, $402-410$ (2011) Chung IM, Seo SH, Ahn JK, Kim SH. Effect of processing, fermentation, and aging treatment to content and profile of phenolic compounds in soybean seed, soy curd and soy paste. Food Chem, 127, 960-967 (2011)

Coward L, Barnes NC, Setchell KDR, Barnes S. Genistein, daidzein, and their $\beta$-glycoside conjugates: Antitumor isoflavones in soybean foods from American and Asian diets. J Agric Food Chem, 41, 1961-1967 (1993)

Donkor ON, Shah NP. Production of $\alpha$-glucosidase and hydrolysis of isoflavone phytoestrogen by Lactobacillus acidophilus, Bifidobacterium lactis, and Lactobacillus casei in soymilk. J Food Sci, 73, 15-20 (2008)

Durmaz G, Alpaslan M. Antioxidant properties of roasted apricot (Prunus armeniaca L.) kernel. Food Chem, 100, 1177-1181 (2007)

Hong JY, Shin SR, Bae MJ, Bae JS, Lee IC, Kwon OJ, Jung JW, Kim YH, Kim TH. Pancreatic lipase inhibitors isolated from the leaves of cultivated Mountain Ginseng (Panax ginseng). Korean J Food Preserv, 17, 727-732 (2010)

Hoppe MB, Jha HC, Egge H. Structure of an antioxidant from fermented soybeans (tempeh). J Am Oil Chem Soc, 74, 477-479 (1997)

Hwang CE, Cho KM, Kim SC, Joo OS. Change in physicochemical properties, phytoestrogen content, and antioxidant activity during lactic acid fermentation of soy powder milk obtained from colored small soybean. Korean J Food Preserv, 25, 696-705 (2018a)

Hwang CE, Haque MA, Lee JH, Ahn MJ, Lee HY, Lee BW, Lee YY, Lee CW, Kim BJ, Park JY, Sim EY, Lee DH, Ko JM, Kim HT, Cho KM. Changes in phytoestrogen contents and antioxidant activities during fermentation of soybean-powder milks prepared from different soybean cultivars by Lactobacillus plantarum P1201. Korean J Microbiol, 52, 202-211 (2016a)

Hwang CE, Haque MA, Lee JH, Joo OS, Kim SC, Lee HY, Um BS, Park KS, Cho KM. Comparison of $\gamma$ aminobutyric acid and isoflavone aglycone contents, to radical scavenging activities of high-protein soybean sprouting by lactic acid fermentation with Lactobacillus brevis. Korean J Food Preserv, 25, 7-18 (2018b)

Hwang CE, Kim SC, Lee JH, Hong SY, Cho KM. Enhanced biological effect of fermented soy-powder milk with 
Lactobacillus brevis increasing in $\gamma$-aminobutyric acid and isoflavone aglycone contents. J Appl Biol Chem, 61, 245-255 (2018c)

Hwang CE, Lee BW, An MJ, Lee HY, Kim HT, Ko JM, Baek IY, Cho KM. Changes of phytochemicals and antioxidant activity during fermentation of brown soymilk. J Agric Life Sci, 50, 157-167 (2016b)

Hwang CE, Lee DH, Kim B, Joo OS, Kim SC, Lee JH, Hong SY, Choi AR, Cho KM. Enhanced digestive enzyme activity and anti-adipogenic of fermented soypowder milk with probiotic Lactobacillus plantarum P1201 through an increase in conjugated linoleic acid and isoflavone aglycone content. Korean J Food Preserv, 25, 461-470 (2018d)

Jeong $\mathrm{KH}$, Seo JH, Jeong YJ. Characteristics of soybean hydrolysates prepared with various protease. Korean J Food Preserv, 12, 460-464 (2005)

Kamiya T. Biological functions and health benefits of amino acids. Foods Food Ingredients J Jpn, 206, 33-44 (2002)

Kim HK, Kwon YJ, Kim KH, Jeong YH. Changes of total polyphenol content and electron donating ability of Aster glehni extracts with different microwave-assisted extraction conditions. Korean J Food Sci Technol, 32, 10221028 (2000)

Kim JS, Kwon $\mathrm{CH}$, Son $\mathrm{KH}$. Inhibition of alpha-glucosidase and amylase by luteolin, a flavonoid. Biosci Biotechnol Biochem, 64, 2458-2461 (2000)

Kim JW, Youn KS. Polyphenolic compounds, physiological activities, and digestive enzyme inhibitory effect of Aster scaber Thunb. extracts according to different extraction processes. J Korean Soc Food Sci Nutr, 43, 1701-1708 (2014)

Ko JM, Han WY, Kim HT, Lee YH, Choi MS, Lee BW, Shin SU, Seo JH, Oh KW, Yun HT, Jeon MG, Choi KH, Shin JH, Lee EJ, Yang S, Oh IS. Soybean cultivar for soy-paste, 'Uram' with mechanization harvesting, large seed, disease resistance and high yield. Korean J Breed Sci, 48, 301-306 (2016)

Kwon OJ, Lee HY, Kim TH, Kim SG. Antioxidant and pancreatic lipase inhibitory activities of Anemarrhena asphodeloides. Korean J Food Preserv, 21, 421-426 (2014)

Lee BH, Lo YH, Pan TM. Anti-obesity activity of Lactobacillus fermented soy milk products. J Funct
Foods, 5, 905-913 (2013)

Lee CH, Yang L, Xu JZ, Yeung SYV, Huang Y, Chen ZY. Relative antioxidant activity of soybean isoflavones and their glycosides. Food Chem, 90, 735-741 (2005)

Lee JH, Hwang CE, Cho EJ, Song YH, Kim SC, Cho KM Improvement of nutritional components and in vitro antioxidative properties of soy-powder yogurts using Lactobacillus plantarum. J Food Drug Anal, 26, 10541065 (2018a)

Lee JH, Hwang CE, Son KS, Cho KM. Comparisons of nutritional constituents in soybeans during solid state fermentation times and screening for their glucosidase enzymes and antioxidant properties. Food Chem, 272, 362-371 (2019)

Lee JH, Kim B, Hwang CE, Haque MA, Kim SC, Lee CS, Kang SS, Cho KM, Lee DH. Changes in conjugated linoleic acid and isoflavone contents from fermented soymilks using Lactobacillus plantarum P1201 and screening for their digestive enzyme inhibition and antioxidant properties. J Funct Foods, 43, 17-28 (2018b)

Lee SY, Kim JH, Park JM, Lee IC, Lee JY. Antioxidant activity and inhibition activity against $\alpha$-amylase and $\alpha$ glucosidase of Smilax china L. Korean J Food Preserv, 21, 254-263 (2014)

Matsuda S, Norimoto F, Matsumoto Y, Ohba R, Teramato Y. Solubilization of a novel isoflavone glycoside-hydrolyzing $\beta$-glucosidase from Lactobacillus casei subsp. rhamnosus. J Ferment Bioeng, 77, 493-441 (1994)

Park JH, Baek MR, Lee BH, Yon GH, Ryu SY, Kim YS, Park SU, Hong KS. $\alpha$-Glucosidase and $\alpha$-amylase inhibitory activity of compounds from roots extract of Pueraria thunbergiana. Korean J Medicinal Crop Sci, 17, 357-362 (2009)

Park JS. Effect on the inhibition of pancreatic lipase and lipid metabolism of Zanthoxylum poperitum extracts. Korean J Food Nutr, 26, 615-619 (2013)

Pratt DE, Pietro CD, Porter WL, Giffee JW. Phenolic antioxidants of soy protein hydrolyzates. J Food Sci, 47, 24-35 (1982)

Pyo YH. Effect of Monascus-fermentation on the content of GABA and free amino acids in soybean. J Korean Soc Food Sci Nutr, 37, 1208-1213 (2008)

Yang M, Kwak JS, Jang SR, Jia Y, Park IS. Antioxidant activity of soybean yogurt added tomato extract by 
Bacillus subtilis and Lactobacillus plantarum. Korean J

Food Nutr, 26, 280-286 (2013)

Youn KS, Chung HS. Optimization of the roasting tempe- rature and time for preparation of coffee-like maize beverage using the response surface methodology. LWT-Food Sci Technol, 46, 305-310 (2012) 